\title{
СЕМАНТИЧНИЙ АНАЛІЗ ТЕМАТИЧНИХ ГРУП ФРАЗЕОСЕМАНТИЧНОГО ПОЛЯ КОНЦЕПТУ ЛЮДИНА
}

\author{
Шепель Ю. О., Федіна О. В.
}

\section{ВСТУП}

Антропоцентризм, підгрунтям якого є концепція В. фон Гумбольдта про мову як «дух народу», розглядає людину з погляду центру та найвищої мети світобудови. Для сучасного стану розвитку науки характерне розмаїття підходів до вивчення людини. Тож, у сучасну епоху актуальності набули наукові розвідки, які пов'язані з описом феномену людини як лінгвокреативної особистості. Зокрема, концепт людина та все, що з ним пов'язане, постає першорядною темою сучасної філософії та соціології, етики й естетики, літератури та мистецтва. Антропоцентризм став загальною тенденцією сучасного лінгвістичного пізнання - рухом від сфери систем до центру цих систем - до людини, і спрямовує свій вектор на опрацьовування тріади «людина - мова - культура».

Під час опису матеріалу виходимо із принципу дослідження «людини в мові», а саме «людини у фразеології».

Лінгвістичний процес опису концептів переважно грунтується на матеріалі лексичних одиниць і паремій, а фразеологізми залишаються поза увагою та здебільшого не стали об'єктом сучасних досліджень. Під час найменування явищ дійсності, фразеологічні одиниці, які відображають оцінку й емоційне ставлення носія мови, фіксують найбільшу кількість національно-культурної інформації: менталітет народу, спосіб його життя, звичаї, вірування, національні стереотипи й еталони, стосунки всередині соціуму, історичні події, словом, - усе те, що $\epsilon$ предметом національної культури й бере участь у формуванні концептуальної картини світу, яка, матеріалізуючись у мові, віддзеркалює мовну картину світу.

Аналіз наукових розвідок з аксіологічної лінгвістики доводить, що антропоцентричні фразеологізми в аксіологічному аспекті не перебували в центрі уваги науковців. Поза увагою залишено також такі фразеологізми, функційні особливості яких вивчають на матеріалі як однісї мови, так і різноструктурних мов.

Отже, актуальність дослідження зумовлена такими чинниками:

1) потребою вивчення й опису концепту людина у фразеології з позиції антропоцентричної парадигми лінгвістики; 
2) вагомістю узагальнення й теоретичного осмислення великого й досить розрізненого лінгвістичного матеріалу, щоб у подальшому визначити його місце в системі порівняльної фразеології та в порівняльній лінгвістиці;

3) попитом на вирішення проблем, що стосуються співвідношення мови, мислення, пізнання й культури, розв'язання яких грунтується на методах когнітивного й лінгвокультурологічного аналізу.

Ми виходимо 3 того, що основна мета лінгвокультурологічного напряму у фразеології полягає у виявленні способів і засобів утілення «мови культури» у зміст фразеологізмів. Фразеологізм - об'єкт лінгвістики, проте лінгвокультурологічний аспект його дослідження дає змогу зрозуміти особливість стійкого сполучення слів як мовного знаку й описати роль фразеології в категоризації концептосфери культури. Предметними галузями дослідження $€$ семантика і прагматика фразеологічних одиниць (далі - ФО).

Дослідження фразеологічної семантики на сучасному етапі неможливе без розгляду ФО в динаміці, без виявлення особливостей їхнього функціонування в мові. Динамічний характер семантичної структури фразеологізмів зумовлений специфікою співвідношення плану їхнього змісту із планом вираження, що зумовлює спроможність ФО до різних модифікацій значення та форми, до структурносемантичних трансформацій у мові.

Отже, актуальність теми зумовлена необхідністю описати лінгвокультурний потенціал фразеологізмів асоціативного поля «людина». Грунтовного дослідження фразеологічного поля «людина» 3 лінгвокультурологічного, а не лише лінгвістичного, підходу досі не було.

Концепт людина розглядаємо як феномен національної культури, який належить до іiі ядра, до системи іiї цінностей, адже фразеологічні одиниці віддзеркалюють культурну та ментальну цінності народу, транслюють культурні стереотипи від покоління до покоління. Наявність великої кількості номінацій досліджуваного концепту свідчить про його номінативну цільність, яку можна розглядати в системі культурно-ціннісних координат: багатостороннє позначення в мові мають ті предмети, процеси та явища позамовної діяльності, які $\epsilon$ для тієї чи тієї культури найціннішими. 3 огляду на це обгрунтованим видається комплексний підхід до опису таких фразеологічних одиниць iз позиції лінгвістичного й екстралінгвістичного підходів, оскільки досліджувані номінативні антропоцентричні фразеологізми містять інформацію, наповнену додатковими асоціативно-емоційним конотаціями. 
Об'єктом дослідження є фразеологічні одиниці російської мови, які називають людину. На відміну від вузького розуміння - тільки фразеологічні зрощення, фразеологічні єдності та фразеологічні сполучення, під фразеологізмом у широкому сенсі, усталеному в лінгвістиці, розуміємо:

1) ФО, які мають форму самостійного речення, та різні звороти розмовно-побутового мовлення (А судьи кто?; А Васька слушает, да ест; Ну как не порадеть родному человечку; Сам себе голова);

2) ФО, які мають форму словосполучення (сардонический смех; вавилонское столпотворение; девичья память; карты в руки; кровь с молоком; вешать нос на квинту; попасть пальцем в небо; на край света).

Тобто під широким розумінням фразеології визнаємо все те, що не $\epsilon$ словом і відтворюється в готовому вигляді. Це критерій узуальний: усі поєднання слів (як непредикативні, так і предикативні), які відтворено в мові відповідно до узусу вживання, зараховуємо до фразеологізмів. Тобто всі стійкі поєднання слів, незалежно від їхніх характерологічних ознак, уналежнюємо до предмета фразеології.

Предметом наукового аналізу постає концепт людина, вербалізований у фразеології російської мови.

В основу роботи покладаємо таку гіпотезу: концепт людина має безліч ознак, досить чітке ядро й розгалужену периферію. Людину в мовній свідомості сприймають неточно, іноді неконкретно, нечітко через те, що мова моделює картину світу від імені суб'єкта-чоловіка, тобто через те, що мова андроцентрична. Основні характеристики концепту людина відображають також наявні моделі гендерної взаємодії.

Mema дослідження - виявити характерологічні ознаки досліджуваного концепту та способи їхньої маніфестації як засобів віддзеркалення образу людини у фразеології російської мови.

Матеріалом дослідження слугує картотека, яка налічує понад 1200 антропоцентричних фразеологічних одиниць російської мови. Джерелом для укладання картотеки стали тлумачні та фразеологічні словники, матеріали, які розміщені на сайтах сучасних періодичних видань, та інше.

Щодо концептуального аналізу фразеологічних одиниць, то, на нашу думку, він дає змогу говорити про розбіжності в системі усталених цінностей лінгвоспільноти, які визначають понятійним навантаженням того чи того символу. Особливим уважаємо місце знака в системі засобів вираження дійсності фразеологією.

\section{1. Фразеологія як репрезентація етнокультурної пам'яті народу}

Російська культура, як і будь-яка інша, сотні років транслює світовій цивілізації ідеали духовності, взаємодопомоги, співчуття, 
милосердя тощо, які відображені в національній мові та іiі фразеологічному фонді, який, зокрема, як етногенетичний код зберігає спадковість i константність національного світобачення та самоідентичності, відображає найважливіші життєві принципи, пор.: На Бога надейся, а сам не плошай; Всякое даяние - благо; Грех не смех, когда придёт смерть; Беда не страшит, а путь укажет; Вся семья вместе, так и душа на месте тощо ${ }^{1}$. Картина російського світу містить різні фрагменти мовних полів, найважливішим із яких для репрезентації його специфіки варто визнати фразеологічне поле.

Фразеологічна картина світу (далі - ФКС) є вербалізованим результатом процесу мислення, пов'язана 3 категоризацією та фразеологічною концептуалізацією дійсності, з фіксацією та поданням в образній формі побуту, традицій, звичаїв і ментальності народу. ФКС - це унікальний семіотико-ментальний конструкт, мовне відображення життя народу, його національного духу, етнічної самосвідомості, що представлені й акумульовані в семантиці фразем, паремій та інших стійких виразів. Під час фразеологічної концептуалізації російської дійсності експлікується феномен вторинної антропологізації мови, пов'язаний із впливом різних картин світу особистості - наївно-побутової, філософської, архетипної, релігійної, міфологічної, художньо-поетичної, наукової, психологічної, конфесійної, етноконфесійної тощо ${ }^{2}$.

Фразеологія $є$ етноспецифічним когнітивно-дискурсивним конструктом, a iii одиниці, як комунікативно-динамічний засіб дискурсивної практики членів соціуму, висловлюють та відбивають етнокультурні та духовно-конфесійні особливості його історичного і цивілізаційного розвитку.

Відповідно до наших спостережень, головним, ключовим фразеоконцептом російської ФКС і російської лінгвокультури виступає концепт людина, у якому відображені найважливіші уявлення російського народу про людину як члена соціуму, в оцінному ключі представлені лінгвістичні характеристики всіх іпостасей буття людини, від зовнішнього вигляду до специфіки поведінки в тих чи тих ситуаціях.

Цікавою і складною є етимологія лексеми людина. Якщо виходити із семантико-дериваційного аналізу, то бачимо, що слово *čelovekъ, як

1 Гончарова Н.Н. Языковая картина мира как объект лингвистического описания. Известия Тульского государственного университета. Гуманитарные науки. 2012. Вып. 2. С. 53-59.

2 Селіванова О.О. Фразеологія у дзеркалі етносвідомості. Світ свідомості у мові. Черкаси, 2012. С. 106. 
протилежне за кількісною семантикою слову *ludbje, висловлює когнітивну ознаку одиничності, тобто «хтось (один) із людей». Іменна семантика «людина» і займенники (неозначені) смислової аспектності «хтось, хто-небудь» нерідко репрезентують ідентичне - у формальному плані - значення. Усі ці значення дають підставу припустити займенниковий параметр праслов'янської одиниці čelovekъ, що дає змогу встановити деяку кореляцію 3 *koli-vekb (регіонально слов'янською формою) - «хто-небудь», перша основа якої є ранньою формою, яка перетворилася у праслов'янській мові на *čele-, *čeli-. Друга основа інтерпретується як «вік», «сила». На підставі наявних етимологічних даних поняття «людина» здебільшого тлумачать через такі когнітивні класифікатори: людина як «дитя роду», як «той, хто має силу», як «Хтось», що означає будь-кого, кожного представника роду. Різні лексикографічні джерела (тлумачні й енциклопедичні) подають такі базові вербальні ідентифікатори зазначеного поняття: людина - це: 1) «створіння»; 2) «істота»; 3) «суб'єкт»; 4) «система». Під час дослідження фразеологічного поля / простору «людина» виявлено факт, який свідчить про те, що семантико-смислова і когнітивно-аксіологічна системність антропокваліфікативних ФО формується головним чином 3 емоцій, культурних настанов, оцінного компонента. У структурі кожного концепту-поняття можна виокремити його складові частини образну (сукупність уявлень, образів, символів), понятійну (мовна репрезентація за допомогою простих і складних номінацій денотатного ряду i / або класу), аксіологічну (семіотична репрезентація етнокультурних духовних, релігійно-конфесійних, моральних, соціальноісторичних, традиційних ціннісних домінант). Максимально репрезентативними мовними одиницями в такому аспекті є фразеологізми та паремії, які можна інтерпретувати як вербалізовану мовну та ментальну свідомість багатьох поколінь носіїв національної мови, що зафіксували в образно-оцінній формі картину світу й образ людини як виразника національного духу ${ }^{3}$.

Фразеологічна картина світу $\epsilon$ вербалізованим результатом когнітивного мислення, яке пов'язане з категоризацією і фразеологічною концептуалізацією дійсності, з фіксацією та зображенням в образній формі побуту, традицій, звичаїв і ментальності народу. ФКС - це унікальний семіотико-ментальний конструкт мовного віддзеркалення життя народу, його національного духу, етнічної самосвідомості, які представлені й акумульовані в семантиці фразем, паремій та інших стійких виразів. У процесі фразеологічної концептуалізації російської дійсності есплікується феномен вторинної антропологізації мови,

\footnotetext{
${ }^{3}$ Телия В.Н. Фактор культуры и возрождение фразеологизмов. Москва, 1977. С. 64.
} 
пов'язаний із впливом різних картин світу людини - наївно-побутової, філософської, архетипної, релігійної, міфологічної, художньо-поетичної, наукової, психологічної, конфесійної, етноконфесійної тощо. Відповідно до проведених спостережень, ключовим фразеоконцептом російської ФКС і російської лінгвокультури визнано концепт людина, у якому відображені найважливіші уявлення російського народу про людину як члена соціуму.

Максимально репрезентативними мовними одиницями в такому аспекті $\epsilon$ фразеологізми та паремії, які можна інтерпретувати як вербалізовану мовну та ментальну свідомість багатьох поколінь носіїв національної мови, що зафіксували в образно-оціночній формі картину світу й образ людини як виразника національного духу.

\section{2. Загальна характеристика фразеосемантичного поля людина}

Мовна картина російського світу містить різні фрагменти мовних полів, найважливішим із яких для репрезентації його специфіки визнаємо фразеологічне (фразеосемантичне) поле (ФСП). 3 одного боку, ФСП належить до універсальних у системі будь-якої мови, а його члени активно вплітаються у процес ідіоматизації, а з іншого - склад, семантика (а також іiі концептуально-прагматична складова частина) членів ФСП багато в чому визначаються екстралінгвістичними чинниками, зокрема культурно-історичними особливостями в житті російського етносу.

Аспекти структурно-семантичного моделювання фразеології сфери людина загалом пов'язані 3 виокремленням чотирьох структурносемантичних моделей: «Людина + оцінно-кваліфікуюча ознака», «Оцінно-кваліфікуюча ознака», «Процесуально-оцінна ознака», «Категорійно-оцінна ознака», які моделюються 3 урахуванням безпосередньо складових компонентів фразеологічного значення.

Семантичне поле концепту людина, за даними лексикографічних джерел (семантичні, ідеографічні, тематичні та тлумачні словники), надзвичайно різноманітне за конкретним значенням своїх компонентів i складне в організаційному плані, оскільки ситуативно воно перегукується з кількома взаємопов'язаними й типовими семантичними сферами та понятійними галузями: фізіологія людини (пов'язане 3 необхідністю задовольняти потреби живого організму в чомусь); соціальні та культурні характеристики, що охоплюють, по-перше, творчу (трудова, побутова і професійна), діяльність, визначаються соціально-економічними, культурно-історичними особливостями розвитку етносу; соціальні й міжособистісні стосунки, комунікація, соціально-економічне становище людини: стану, пов'язаному з потребою в чомусь; стереотипи поведінки - узагальнене уявлення про 
поведінку людини та ї̈ манери; мовленнєва поведінка як сукупність мовних вчинків.

Різні групи та підгрупи СП людина відіграють різну роль у формуванні російської фразеології, що деякою мірою пов'язано з важливістю різних сторін семантичної сфери «людина» у російській мовній картині світу.

Опрацьовування особливостей мови останнім часом виразно відбиває підвищену увагу лінгвістів до структури лінгвістичних полів. Проте класифікація мовних полів у сучасній лінгвістиці та їх визначення залишається питанням відкритим, без чіткої відповіді. Лінгвісти виокремлюють декілька видів полів: лексичне, семантичне, асоціативне та функційно-семантичне. У зв'язку 3 інтенсивним розвитком польового підходу під час дослідження мови останнім часом відтіняють інші види полів, як-от: комплексні, фразеосемантичні. Термін «поле» зазвичай уналежнюють до широких груп слів, визначають співвідношення понять «структура» й «система», говорять про ядро та периферію мовної системи, по-різному вивчають ці поняття. Проте можна впевнено стверджувати, що ядро формується навколо компонента-домінанти, а периферію становлять віддалені одиниці. Периферійні одиниці можуть вступати в контакт 3 іншими семантичними полями, утворювати лексико-семантичну неперервність мовної системи. Перехід від ядра до периферії здійснюється поступово, тому чіткої межі між ядром і периферією не можна спостерігати. Усі лексичні одиниці віддалені на різну відстань від ядра, що дає змогу науковцям говорити про ближню та дальню периферію.

Отже, поля, які визначаються на основі певних ознак, є системними формуваннями із притаманними їм відношеннями та зв'язками для будь-якої системи і водночас своїми специфічними рисами. Однією 3 рис поля є можливість об'єднувати у своєму складі гетерогенні мовні засоби, які належать до різних класів або мовних рівнів. Від ядра до периферії рух відбувається поступово, позначаються певні периферійні зони, по-різному віддалені від ядра. У своєму складі поле спроможне поєднувати кілька мікрополів, яким властива відносна самостійність ${ }^{4}$.

Фразеологічну цілісність мають не лише фразеологізми, але й вільні словосполучення. Виходимо з того, що головним показником ФО має бути не лише семантичний, але й диференційний показник, адже під час семантичного перетворення в межах фразеологізації план змісту і план вираження не збігаються ${ }^{5}$. Семантичне перетворення - основна

${ }^{4}$ Адмони В.Г. Основы теории грамматики. Москва ; Ленинград : Наука, 1964. С. 42.

${ }^{5}$ Див. також думку: Назарян А.Г. История развития славянской лексикологии. Москва, 2011. 143 с. 
ознака фразеологічних одиниць мови, що дає змогу відмежувати їх від стійких зворотів (див. таблицю 1). Отже, можна сказати, що значення окремих елементів ФО, план вираження цих одиниць не збігаються зі значенням усього фразеологізму - планом змісту.

Таблиця 1

Семантичне перетворення в межах фразеологізації

\begin{tabular}{|c|c|}
\hline Стійкий вираз & Нестійке значення ФО \\
\hline разжигать ссору & усиливать конфликт \\
\hline тянуть все кишки & утомлять до бессилия \\
\hline выросли крылья & стало очень приятно \\
\hline шут гороховый & посмешище \\
\hline Царевна Несмеяна & депрессивный человек \\
\hline Фома неверуюшчии & недоверчивый человек, \\
который во всем видит подвох
\end{tabular}

Фразеоконцепm визначаємо як дискретне ментальне утворення, яке має відносно впорядковану структуру відповідно до законів упорядкування та гармонізації елементів реального світу, що формується на засадах почуттєвого та раціонального сприйняття світу представниками тієї чи тієї етнокультури. Фразеоконцепт об'єктивується фразеологічними одиницями під час взаємодії семіотичних засобів мови, когніції та культури. Він утворюється за допомогою мікроконцептів, вербалізованих фразеологічними одиницями, які згруповуються на основі єдності поняття, що відображає ту чи ту рису характеру людини, і єдності відображуваних семантичних ознак. Фразеоконцепт «людина» охоплює образноасоціативний шар, експлікований когнітивними ознаками й образом, що відсилає концепт до матеріального світу; інтерпретаційний шар, що містить мінімум когнітивних ознак, які визначають суттєві відмінні диференційні риси поняття «людина»; прагматичний шар, який зберігає ціннісну інформацію про ставлення етносу до визначеного фрагмента дійсності, а саме до тієї чи тієї риси характеру. 
Фразеосемантичне поле моделюємо 3 урахуванням визначених основних змістових аспектів фразеоконцепту.

\section{3. Тематичні групи фразеологічних одиниць із компонентами, які об'єктивують концепт людина}

Дібраний матеріал становить 122 ФО з компонентами, що позначають людину через вільне вживання ознаки речовини. У цьому матеріалі кількісно найбільше представленими виявилися такі речовинні іменникиб: кров (кровинка) - 15; вода - 11; мізки - 10; земля - 7. Інші компоненти назви речовини утворюють від однієї до п’яти ФО.

Кількісний аналіз підгруп іменників свідчить про нерівномірність їхнього розподілу під час вербалізації концепту людина у ФО. Найуживанішими виявились іменники, що позначають страви і продукти харчування. Це пов'язано, на нашу думку, з повсякденним життям людини, iіi фізіологічними потребами в їжі. Звідси, наприклад, моделюємо низку асоціацій, що виникають через ФО (пор.: жир товста, огрядна людина, вино - сп'яніла, мед - ніжна, улеслива тощо). Наприклад: Главное, она была уж очень толстенькая, настоящий жиртрест, хотя бегала быстро и на уроках физкультуры обгоняла других девчонок (Юрий Трифонов. «Дом на набережной»).

Лексичні та фразеологічні одиниці мови по-різному фіксують й інтерпретують концептуальну організацію поняття «людина». Так, матеріал дає змогу стверджувати, що іменники як компоненти ФО втрачають частину своїх семантичних елементів, гублять здатність позначати хімічні речовини (соль земли - «найкращі, найталановитіші, дієздатні, корисні для суспільства люди»), продукти харчування (не в капусте найденный - «не гірший за інших; такий, як усі») та інші види речовин.

Зазначимо, що у формуванні ФО з колишнім речовинним іменником важливу роль відіграє саме індивідуальне значення лексеми. Наприклад, ФО куриные мозги - «про людину невеликого розуму, обмежених розумових здібностей»; чугунные мозги - «про дуже дурну, нерозумну людину; тугодума»; [Голова] без мозгов - «про безглузду, дурнувату людину»; мозги набекрень - «про людину нетямущу, дурнувату, із примхами»; мозга за мозгу заходит - «про того, хто втрачає здатність тверезо, розумно міркувати, діяти», характеризують людину з погляду їі інтелектуальних, ментальних здібностей й утворені

6 Під терміном «речові іменники» розуміємо іменники, що позначають у фразеологізації однорідні за своїм складом речовини, які піддаються вимірюванню, але не підрахунку, які можна ділити на частини, коли кожна 3 них має властивості цілого. 
на базі вторинного, переносного значення лексеми «мозок» - «розум, розумові здібності».

Речовинні іменники, які є компонентами ФО на позначення людини, зараховуємо до таких тематичних груп:

1. Хімічні речовини, органічні й хімічні поєднання (порох, дылмина (прост.), газ, косточка, кровь, соль, песок, миро, земля - в зн. «почва», «ладан», «пыль»).

2. Рослини, злаки (ягода, капуста, огурчик, горох (горошина), солома, лимон, сено, хрен, крупа).

3. Корисні копалини (золото).

4. Продукти харчування, страви (хлеб, вода, кисель, сливки, закваска, каша, тесто, вино, пиво, мясо, жир, мед, квашня, щии, масло, лапиа, молоко, сахар).

5. Промислова продукція, тканини, волокна (oтбросbl, труха, корм, шкура, мякина, кожа, пух, лько, мощчи, полотно, шерсть, мозги).

6. Речовина як результат будь-яких природних процесів або видів людської діяльності (грязь, сопли, снег, лед, моча, мыло, слезы, nот).

До першої групи уналежнюємо фразеологізми 3 негативним суб'єктивно-оцінним компонентом фразеологічного значення, тобто ФО зі значенням «осуд як констатація соціально усталеної оцінки певних рис характеру»: лукавство, лицемірство (волк в овечьей шкуре); підлість (рыльце в пуху); зарозумілість, (пуп земли); жадібність (зимой снега (снегу) не выпросишь); хитрість, улесливість (сахар-медович; кока с соком); грубість, нестриманість, запальність (моча в голову ударила; не сахар; не мед); уїдливість, надокучливість (ест как ржа (железо)); нерішучість, безвілля, посередність (ни рыба, ни мясо; пороху не хватает); впертість (пива (каши) не сваришь); байдужість, черствість (как земля только носит; толстая шкура; как с гуся вода, холоднылй как лёд; рыбья кровь); дурість, некмітливість (как об стенку горохом; куриные мозги; иыллячьи мозги; чугунные мозги; каша в голове; мозги набекрень; мозги не варят; сено-солома; мозги не туда повернуты; голова мякиной набита; лопух лопухом; министр кисльх щуей); егоїзм (как собака на сене); злість (купоросное масло); зіпсованість, розбещеність (приниесса на горошине); низький інтелектуальний розвиток, нерозумність (профессор кисльх щуей).

До другої групи уналежнюємо ФО з позитивним суб'єктивно-оцінним компонентом фразеологічного значення, тобто ФО зі значенням «схвалення як констатація соціально усталеної оцінки певних рис характеру людини»: сміливість, мужність (в огне не горит, в воде не тонет); стриманість, спокій, скромність (тише воды; тише воды, ниже травы; воды (водою) не замутить); рішучість, палкість, сильний характер, 
надійність (твёрдый (крепкий) орешек; крепкой закваски; старой закваски; кровь горяча); працьовитість, активність, діяльність (землю роет; хлебом не корми; рабочая косточка); життєрадісність (с порохом); дієздатність, вміння (не лыком шитый). Наприклад: Зимой снега (снегу) не выпросишь (у кого?) (разг., презр.) «о скупом, жадном человеке»: Она узнавала прежнего Корнилу, у которого, говорили, зимой снега не выпросишь (В. Быков. «Знак беды»); Тише воды, ниже травы - (разг.) «робкий, скоромный, незаметный или, чаще, старающийся выглядеть таким в силу тех или иных обстоятельств»: И стань она, Дарья, в положении Симы - тоже была бы тише воды, ниже травы! (В. Распутин. «Прощание с Матёрой»).

Загальну семантичну асиметрію системи ФО (зрушення в бік негативних значень) можна пояснити гострішою емоційною та мовленнєво-мисленнєвою реакцією людей саме на негативні явища, а також характерною для різко негативних емоційних станів тенденцією до використання фразеологічних одиниць. Отже, соціальний аспект особистості - усвідомлення особистого «я», свого внутрішнього світу і ставлення до зовнішнього світу - важлива складова частина сутності людини.

Фразеологізми, що номінують людину за соціальними властивостями, семантично представлені в 5 групах. Найбільшими в кількісному відношенні є такі:

1. «Соціальний статус людини» - 5 ФО (из грязи в князи; голубая кровь; сливки общества; отбросы общества; чистой (чистых, высоких) крови (кровей)).

2. «Міжособистісні відносини» -8 ФО. Людину в російській мовній картині світу постійно порівнюють з іншою людиною, і якщо порівнювані особи виявляють схожими за характером, поведінкою, соціальним статусом або за іншими характеристикам особистості, то про них говорять: одного поля ягода; из одного теста сделаны; черти одной шерсти; одним миром мазаны. А якщо порівнювані суб'єкти різні, то кажуть: как небо и земля; лед и пламень; испечен из другого теста.

3. Дружні стосунки вербалізують ФО 3 компонентом-назвою речовини (водой не разольешь (не разлей вода).

Шість - сім ФО віднесено до груп:

4. «Місце і роль людини в суспільстві» (соль земли; как с козла молоко; на вес золота; не в капусте (найден) подобран; пушечное мясо; как синь порох в глазу; земля держится).

5. «Сімейні стосунки» (одной крови; кровь от крови; седьмая (десятая) вода на киселе; кровь заговорит; как две капли воды; на восьмой воде). 
До (6) лексико-тематичної групи уналежнюємо ФО з компонентом назвою речовини, що характеризують людину за зовнішніми ознаками (ни рожи ни кожи; кровь с молоком; ни кровиночки в лице; белый как полотно; соплей перешибешь); за віком (молоко на губах не обсохло; сопли под носом; сопля зелёная; в полном соку; песок (труха) сыплется; старый хрен; мало каши ел; пороху не нюхал; Божий одуванчик); зростом (от земли не видеть); за вагою (жир-трест; лопаться с жиру; кости да кожа; рассиживаться как квашня; легче пуха; как пушинка; живые (ходячие) мощи); за фізіологічним та психічним станом (пьяней вина; как огурчик; под парами; в дымину; под газом (газком); кровь кипит (играет); кровь леденеет (хладеет) в жилах; кровь разыгралась; кровь стынет (застывает) в жилах; кровь бурлит; кровь вскипает (закипает) в жилах; мозга за мозгу заходит; будто каши (воды) в рот набрал; как в воду опущенный; на ладан дымит; лыка не вяжет; выжатый лимон; (весь) в мыле; как мышь на крупу; в слезах). Пор.: Как в воду опущенный - «подавленный, чем-то угнетенный, удрученный»: Как батюшка просватал её за какого-то большого польского пана, так она с тех пор как в воду опущенная (М. Загоскин. «Юрий Милославский»).

В основі утворення фразеологізмів із концептом людина в багатьох прикладах спостерігаємо механізми метафоричного / метонімічного переосмислення. Частина фразеологізмів з'являються за допомогою метафори, пор.: пуп земли; отбросы общества, порівняння (как небо и земля; ест как ржа; как огурчик; будто каши в рот набрал; как синь порох в глазу), гіперболи (в огне не горит, в воде не тонет; кровь бурлит; от земли не видать); алітерації та рими (сено-солома; жиртрест; из грязи в князи; кока с соком тощо).

Усередині аналізованих лексико-семантичних груп переважно спостерігаємо як синонімічні відношення, наприклад, синоніми зі значенням «старий» (Божий одуванчик; старый хрен; песок сыплется); «худий» (кости да кожа; легче пуха; как пушинка); «дурний» (цыплячьи мозги; куриные мозги; чугунные мозги), так і антонімічні відношення, наприклад, антоніми зі значенням «п'яний» (под газом, пьяней вина), «тверезий» (как огурчик).

Дібраний фактичний матеріал дає змогу стверджувати, що більшість фразеологізмів із компонентом - назвою речовини, які вербалізують концепт людина, належать до розмовного стилю.

\section{ВИСНОВКИ}

Фразеологічна одиниця як спосіб фіксації поняття в мові спочатку має у своєму розпорядженні групу смислових орієнтацій (пресуп- 
позицій), що реалізуються в мовленнєвій діяльності. Залежно від намірів суб'єкта й залежно від ситуації відбувається реалізація тих чи тих пресуппозицій. Установлюються нові понятійні та семантичні зв'язки між мовними знаками.

Слова-компоненти у складі фразеологічної одиниці сигналізують про «початковий денотат», який був певним чином інтерпретований суб'єктом, що й слугує основою формування мовного значення стійкого сполучення слів. Звідси випливає, що фразеологічна одиниця це застиглий у мові досвід пізнання народу.

Оскільки етномова нерозривно пов'язана 3 етнокультурою, що виявляється в постійному вливанні культурних кодів в етномову, а саме у сфери образної лексики, фразеології та пареміології, фразеологічний фонд на образному рівні $\epsilon$ одним із природних утілень низки культурних кодів, субкодів і фрагментів.

Слово називає, а ФО виражає ставлення. Водночас прагматичний аспект ФО виражений набагато сильніше, ніж у лексичної одиниці, навіть якщо вона вживається в переносному образному значенні. Прагматичний компонент значення ФО превалює над денотативним, тому специфічність фразеологічного значення полягає передусім в ідеографічній націленості на експресивно-емоційні сфери найменування реалій.

Фразеологізми 3 назвами людей у лексичному наповненні відзначаються великим діапазоном сфер використання. Спостереження говорять про різноплановість характеристик, кваліфікованих названими ФО. Людина як еталон освоєння різних категорій буття дала поштовх до виникнення фразеологізмів, що функціонують для називання фрагментів як матеріального, так і нематеріального світу.

Проте людину першочергово усвідомлюють як істоту біологічну, що відповідним чином відбивається в семантиці фразеологічних мовних засобів. Зокрема, нами виокремлено ФО, у значеннєвій структурі яких домінантними є семи, які маніфестують низку емоцій і почуттів (від захоплення до відрази) і актуалізують модальну оцінку: батюшки, твою мать, черт его знает, чертово отродье, чертова баба, матерь божья, аллилуйя тощо.

Серед аспектів вияву людської діяльності в мові є:

1) формування картини світу в мові та створення мовного інвентарю;

2) породження мовлення;

3) роль людини у процесі комунікації.

Семантична структура фразеологізмів унікальна та складна. Фразеологічне значення - явище динамічне, викликане особливою 
взаємодією форми та змісту, що приводить до виникнення абстрактного значення. Особливостями фразеологічного значення $\epsilon$ семантична деталізація та стилістична маркованість ФО як наслідок сполучення смислів конституентів, їхня поліденотативність, здатність називати різні фрагменти дійсності. Фразеологічне значення складається з упорядкованих сем, співвідносних із певними якостями та явищами дійсності. Значення ФО образно вмотивоване, більш насичене нюансами, певними деталями, ніж значення окремого слова.

Прийом структурно-семантичного (польового) дослідження лінгвістичного континууму в загальному вигляді підпорядковується таким чинникам: класифікація повинна спиратися на повну, логічно зумовлену схему, яка буде підкреслювати існування цілісної «тканини» мовної картини світу, у якій кожна одиниця буде посідати відповідне місце вираження; за основну одиницю ідеографічної класифікації обирається семантичний клас, ознаки якого нейтралізуються в певних контекстах; відношення між класами відображаються схемою класифікації понять; класифікація фразеології / лексики оперує словами-поняттями, а не багатозначними словами (висловлюваннями); під час віднесення слова до певного семантичного класу потрібно звертати увагу на явище гіперболізації значень слів, наявність «дифузії» у його межах; у визначених тематичних групах слів.

\section{АНОТАЦІЯ}

Розділ присвячено описові основних положень лінгвокультурного підходу в частині структурної організації концепту людина, дослідженню особливостей співвідношення елементів цього лінгвокультурного концепту та семантики фразеологічних одиниць, що набули поширення як у художній, так і в науковій літературі. Концепт людина та все, що 3 ним пов'язане, постає першорядною темою сучасної філософії та соціології, етики й естетики, літератури та мистецтва. Роздуми авторів посилаються на те, що антропоцентризм став загальною тенденцією сучасного лінгвістичного пізнання - рухом від сфери систем до центру цих систем, а саме до людини, і спрямовує свій вектор на опрацьовування тріади «людина - мова - культура». В опис матеріалу покладено принцип дослідження «людини в мові», а саме «людини у фразеології».

Актуальність порушуваної теми дослідження зумовлена необхідністю описати лінгвокультурний потенціал фразеологізмів асоціативного поля «людина». Автори ставлять за мету виявити характерологічні ознаки досліджуваного концепту, способів їхньої 
маніфестації як засобів віддзеркалення образу людини у фразеології російської мови.

У розділі розкрито питання концепту та фразеосемантичного поля, акцентовано увагу на тому, що наявність у мові фразеологізмів, що поєднані в загально переосмислений спосіб, на позначення людини свідчить про наявність прототипної ситуації, яка може провокувати появу в культурі певного цінного ставлення. За кількістю наявних у мові фразеологічних одиниць, які номінують той чи той моральний принцип або моральне почуття людини, варто говорити про значущість цього принципу або почуттів у межах культури.

Визначено, що процес мовної концептуалізації уможливлює формування концепту людина як одиниці концептуальної системи і структури знань. Аналіз антропоцентричних номінативних фразеологізмів на позначення людини в російській мові свідчить, що вони відтворюють спосіб світобачення народу та можуть бути визначені в межах культурних кодів як сукупність окультурених уявлень про картину світу. Мовна специфіка аналізованих фразеологічних одиниць виражена в їхньому образному наповненні цих одиниць іта пов'язана з культурними й національними особливостями носіїв мови.

Аналіз функціонування фразеологічних одниць не лише виявляє їхню багатозначність, а й розширює уявлення про сферу використання. Фразеологізми, що характеризують людину, широко вживають у текстах різних стилів і жанрів, з різним смисловим навантаженням: у будь-яких публіцистичних текстах (з політичним, економічним, юридичним спрямуванням), а також у художніх текстах як зображально-виразний засіб. Отже, досліджуваний мовний матеріал виявляє як загальні риси, властиві різним народам, так і індивідуальні.

Перспективу подальшого дослідження вбачаємо у вивченні фразеологічних одиниць, які називають людину, для поглибленого дослідження мовної картини світу, оскільки описуваний аналіз структури концепту можна використати:

1) під час виявлення й описання діахронічних змін, які сталися в національній концептосфері мови;

2) для подальшого виявлення креативності особистості через утворення нових фразеологічних одниць, тобто динаміки розвитку останніх від словосполучення до ідіоми.

\section{ЛІТЕРАТУРА}

1. Адмони В.Г. Основы теории грамматики. Москва ; Ленинград : Наука, 1964. 104 с. 
2. Гончарова Н.Н. Языковая картина мира как объект лингвистического описания. Известия Тульского государственного университета. Гуманитарные науки. 2012. Вып. 2. С. 53-59.

3. Назарян А.Г. История развития славянской лексикологии. Москва, 2011. 143 с.

4. Селіванова О.О. Фразеологія у дзеркалі етносвідомості. Світ свідомості у мові. Черкаси, 2012. 308 с.

5. Телия В. Н. Фактор культуры и возрождение фразеологизмов. Москва, 1977. 260 с.

\section{Information about the authors:} Shepel Yu. O.,

Doctor of Science (Philology), Full Professor, Academician at the National Academy of Sciences of Higher Education of Ukraine, Professor at the Department of Translation and Linguistic Training of Foreigners

Oles Honchar Dnipro National University 72, Gagarin avenue, Dnipro, 49700, Ukraine

Fedina O. V., Candidate of Sciences (Philology), Lecturer

Dniprovsk Professional College of Engineering and Pedagogical of the Ukrainian State University of Chemical Technology 10, Medychna str., Kamianske, Dnipropetrovsk region, 51931, Ukraine 